\title{
Diversity of Neural Precursors in the Adult Mammalian Brain
}

\author{
Michael A. Bonaguidi1 ${ }^{1,2,3,7}$, Ryan P. Stadel ${ }^{1,4}$, Daniel A. Berg, ${ }^{1,2}$, Jiaqi Sun ${ }^{1,5}$, Guo-li Ming ${ }^{1,2,3,6}$, \\ and Hongjun Song $1,2,3,4,6$ \\ ${ }^{1}$ Institute for Cell Engineering, The Solomon H. Snyder Department of Neuroscience, Johns Hopkins University \\ School of Medicine, Baltimore, Maryland 21205 \\ ${ }^{2}$ Department of Neurology, The Solomon H. Snyder Department of Neuroscience, Johns Hopkins University \\ School of Medicine, Baltimore, Maryland 21205 \\ ${ }^{3}$ Adrienne Helis Malvin Medical Research Foundation, New Orleans, Louisiana 70130-2685 \\ ${ }^{4}$ Human Genetics Predoctoral Program, The Solomon H. Snyder Department of Neuroscience, Johns Hopkins \\ University School of Medicine, Baltimore, Maryland 21205 \\ ${ }^{5}$ School of Life Sciences, Tsinghua University, Beijing 100084, China \\ ${ }^{6}$ The Solomon H. Snyder Department of Neuroscience, Johns Hopkins University School of Medicine, \\ Baltimore, Maryland 21205 \\ Correspondence: mbonagui@usc.edu
}

Aided by advances in technology, recent studies of neural precursor identity and regulation have revealed various cell types as contributors to ongoing cell genesis in the adult mammalian brain. Here, we use stem-cell biology as a framework to highlight the diversity of adult neural precursor populations and emphasize their hierarchy, organization, and plasticity under physiological and pathological conditions.

$T^{\mathrm{T}}$ he adult mammalian brain displays remarkable structural plasticity by generating and incorporating new neural cell types into an already formed brain (Kempermann and Gage 1999). Largely restricted within the subventricular zone (SVZ) along the lateral ventricle and the subgranular zone (SGZ) in the dentate gyrus (DG), neural genesis is thought to arise from neural stem cells (NSCs) (Ming and Song 2011). Stem cells are defined by hallmark functions: capacity to self-renew, maintenance of an immature state over a long duration, and ability to generate specialized cell types (Fig. 1). These features distinguish stem cells from committed progenitor cells that more readily differentiate into specialized cell types (Fig. 1). Stem and progenitor cells (collectively called precursors) are additionally characterized by their lineage capacity. For example, multipotential neural precursors generate neurons and glia, whereas unipotential cells produce only one cell type, such as neurons (Gage 2000; Ma et al. 2009). The classical NSC definition is based on cell culture experiments in which a single cell can self-renew and generate neurons, astrocytes, and oligodendrocytes (Gage 2000; Ma et al. 2009).

\footnotetext{
${ }^{7}$ Current address: Department of Stem Cell Biology and Regenerative Medicine, Eli and Edythe Broad Center for Regenerative Medicine and Stem Cell Research, W.M. Keck School of Medicine, University of Southern California, Los Angeles, CA 90033. Editors: Fred H. Gage, Gerd Kempermann, and Hongjun Song Additional Perspectives on Neurogenesis available at www.cshperspectives.org

Copyright (C) 2016 Cold Spring Harbor Laboratory Press; all rights reserved; doi: 10.1101/cshperspect.a018838 Cite this article as Cold Spring Harb Perspect Biol 2016;8:a018838
} 
M.A. Bonaguidi et al.

A

Stem cell

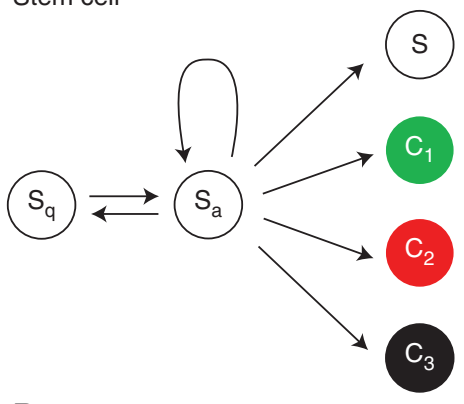

B

Progenitor cell
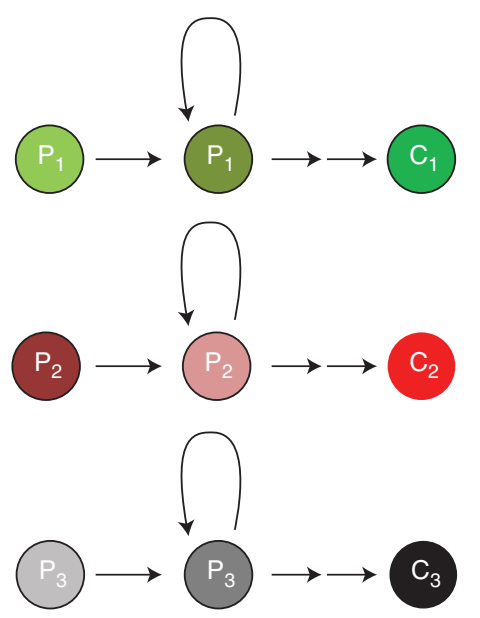

C

Precursor cell input

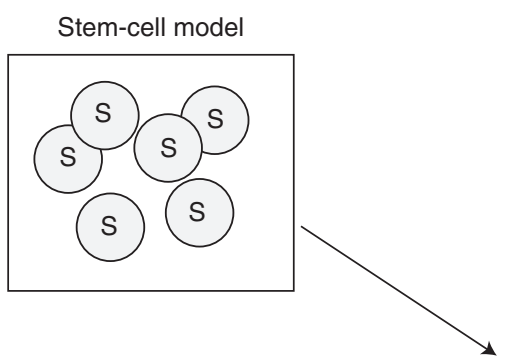

Progenitor-cell model
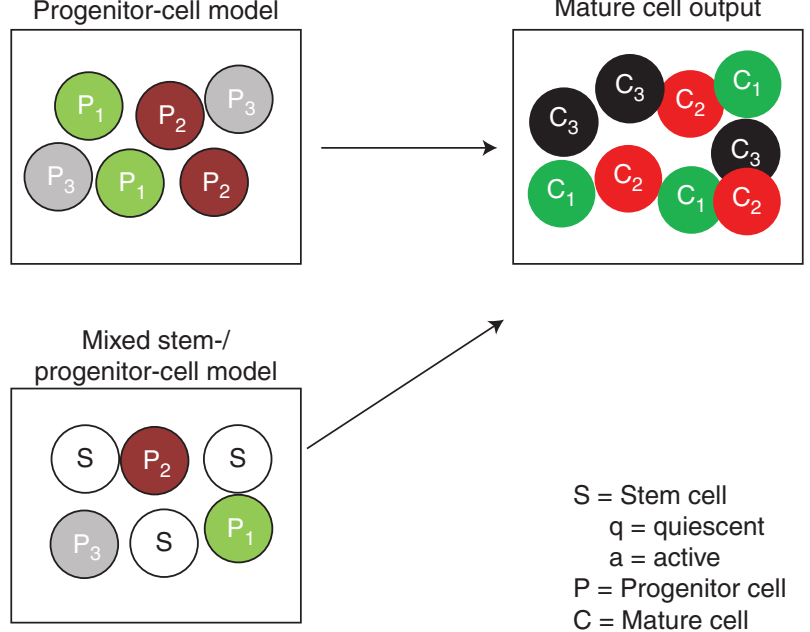

$S=$ Stem cell

$q=$ quiescent

$\mathrm{a}=$ active

$\mathrm{P}=$ Progenitor cell

$\mathrm{C}=$ Mature cell

Figure 1. Models of generating cell diversity in the adult tissues. $(A, B)$ Definitions of stem and progenitor cells. In $A$, quiescent stem cells $\left(\mathrm{S}_{\mathrm{q}}\right)$ become active stem cells $\left(\mathrm{S}_{\mathrm{a}}\right)$ that proliferate to generate different types of specialized cells $\left(\mathrm{C}_{1}, \mathrm{C}_{2}, \mathrm{C}_{3}\right)$ and new stem cells $(\mathrm{S})$. The active stem cell can return to quiescence and remain quiescent over long periods of time. In $B$, lineage-restricted progenitor cells lacking self-renewal capacity $\left(\mathrm{P}_{1}, \mathrm{P}_{2}, \mathrm{P}_{3}\right)$ each give rise to distinct populations of specialized cells $\left(\mathrm{C}_{1}, \mathrm{C}_{2}, \mathrm{C}_{3}\right) .(C)$ Generation of specialized cells in a tissue could be explained by three models. (1) The stem-cell model, in which multipotent stem cells give rise to all the specialized cells in the tissue. (2) The progenitor cell model, in which diverse, lineage-restricted progenitor cells give rise to different cell types in the tissue. (3) A hybrid model, in which a mixture of stem cells and lineagerestricted progenitor cells generate specialized cells of the adult tissue.

Yet, reprogramming studies have raised the question of whether cultured lineage-restricted neural progenitors acquire additional potential not evident in vivo (Palmer et al. 1999; Kondo and Raff 2000; Gabay et al. 2003). As a result, various lineage models have been proposed to explain cell generation in the adult brain (Fig. 1) (Ming and Song 2011). In one model, bona fide adult stem cells generate multiple lineages at the individual cell level. In another, cell genesis rep- resents a collective property from a mixed population of unipotent progenitors. Importantly, these models are not mutually exclusive as evidence for the coexistence of multiple precursors has been observed in several adult somatic tissues, in which one population preferentially maintains homeostasis and another serves as a cellular reserve (Li and Clevers 2010; Mascre et al. 2012). Recent technical advances, including single-cell lineage tracing (Kretzschmar and 
Watt 2012), have made it possible to dissect basic cellular and behavioral processes of neural precursors in vivo (Table 1 ) and have revealed diverse neural precursor populations coexisting within classical neurogenic zones (see Fig. 4) (Bonaguidi et al. 2012). In this work, we review our current knowledge of precursor cell identity, hierarchical organization, and regulation to examine the diverse origins of cell genesis in the adult mammalian brain.

\section{HIERARCHICAL PRECURSOR CELLS IN THE ESTABLISHED ADULT NEUROGENIC NICHE}

Classically, cell lineages are arranged in a hierarchy with cells of the greatest plasticity at the top and fully differentiated cells at the bottom (Waddington 1957). In the adult brain, NSCs represent the top layer followed by restricted neural progenitors and finally specialized cell types: astrocytes, oligodendrocytes, and neurons (Fig. 2). In the prevalent model of adult neurogenesis, radial cells (SGZ: radial glia-like

Table 1. Comparison of different methods used to study the generation of new cells in the adult mammalian nervous system

(1) In vivo imaging allows real-time visualization of cells in their natural environment.

(2) Lineage tracing is the utilization of transgenic animals to label single precursor cells and retrospectively analyze the fate choices made by these cells.

(3) Fate mapping entails the study of lineage decision made by populations of cells, utilizing either using transgenic animals or administration of thymidine analogues.

(4) Adenovirus, lentivirus, and retrovirus, when injected into the brain, can be used to trace single cells or population of cells depending on the virus used and the amount of virus injected into the animals.

(5) Transplantation of precursor cells is a useful tool to examine the intrinsic and extrinsic regulation of precursor cells in the brain.

(6-7) Ex vivo methods involve sections in the brain being maintained in culture media, whereas in in vitro studies, the dissociated cells are cultured either as neurospheres or in a monolayer culture system. cell [RGL], or type 1 cells; SVZ: type B cells) act as NSCs to generate committed proliferative precursors known as intermediate progenitors (SGZ: intermediate progenitor cells [IPCs], or type 2 cells; SVZ: type $C$ cells), which give rise to neuroblasts (SGZ: type 3 cells; SVZ: type A cells) and then immature neurons (Fig. 2). Emerging in vivo evidence indicates that astroglial and oligodendrogial lineages could also arise from lineage-restricted progenitor cells (Zhu et al. 2011). Although these hierarchical relationships exist under physiological conditions, neural precursors' capacity and therefore hierarchical position may alter on injury or exposure to ectopic molecular cues (Palmer et al. 1999; Kondo and Raff 2000; Gabay et al. 2003). Therefore, each experimental approach used to examine stem-cell properties and establish hierarchical relationships requires careful consideration of the cellular and molecular context as well as an understanding of the precursor cells initially targeted. Precursor diversity may occur at any of the three hierarchical levels owing to (1) different cell-type identities, and the heterogeneity within a cell type based on its (2) behavior/ lineage capacity, and/or (3) function under environmental alterations.

\section{Putative NSCs}

Radial glia-like precursor cells are characterized by the expression of nestin, glial fibrillary acidic protein (GFAP), Sox2, and possess a defining radial branch that extends through the granule cell layer in the dentate or contacts blood vessels in the SVZ (Fuentealba et al. 2012). In both niches, radial cells display a relatively quiescent nature that distinguishes them from nonradial and intermediate progenitors (Morshead et al. 1994; Lugert et al. 2010). Evidence from both physiological and nonphysiological approaches, including population level transgenic fate mapping (Ahn and Joyner 2005; Lagace et al. 2007; Dranovsky et al. 2011), genetic ablation (Garcia et al. 2004), and antimitotic treatment recovery (Seri et al. 2001), suggest radial cells exist atop the cellular hierarchy. In the adult SGZ, the neuronal and astroglial lineages, but not the oligodendrocyte lineage, are generated under physi- 
A

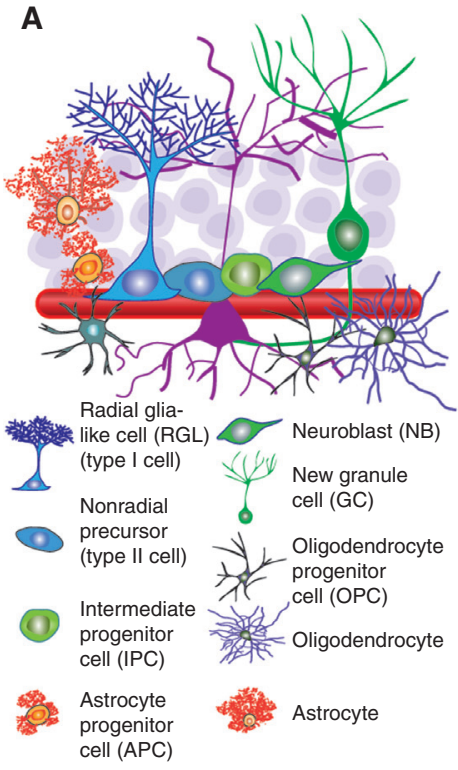

B

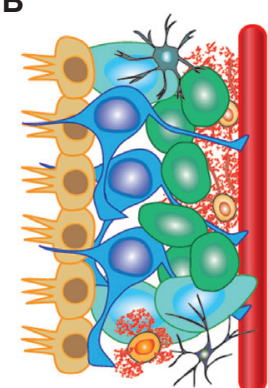

$\mathbf{A}^{\prime}$

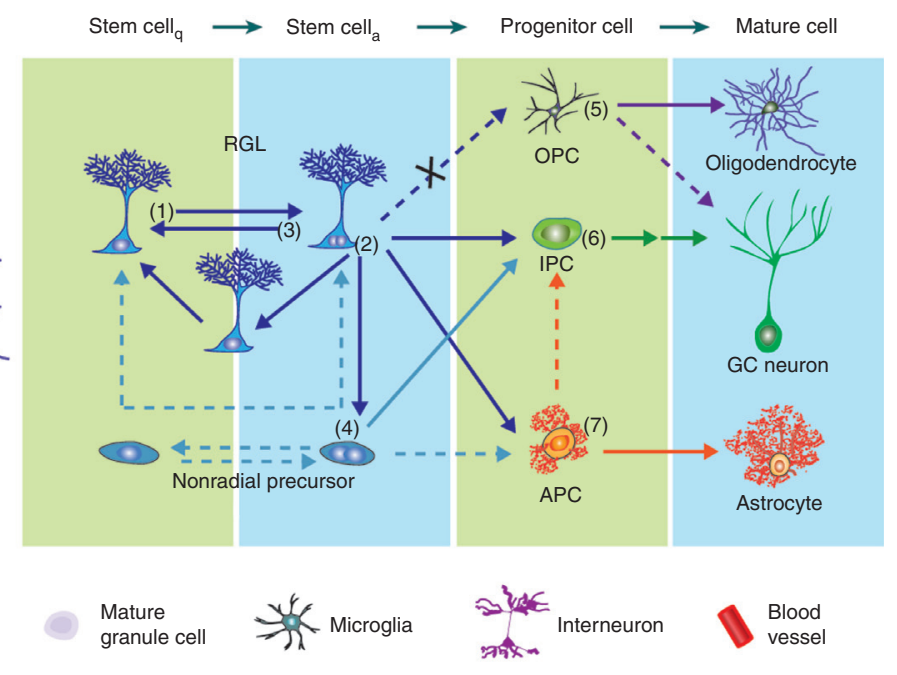

$\mathbf{B}^{\prime}$

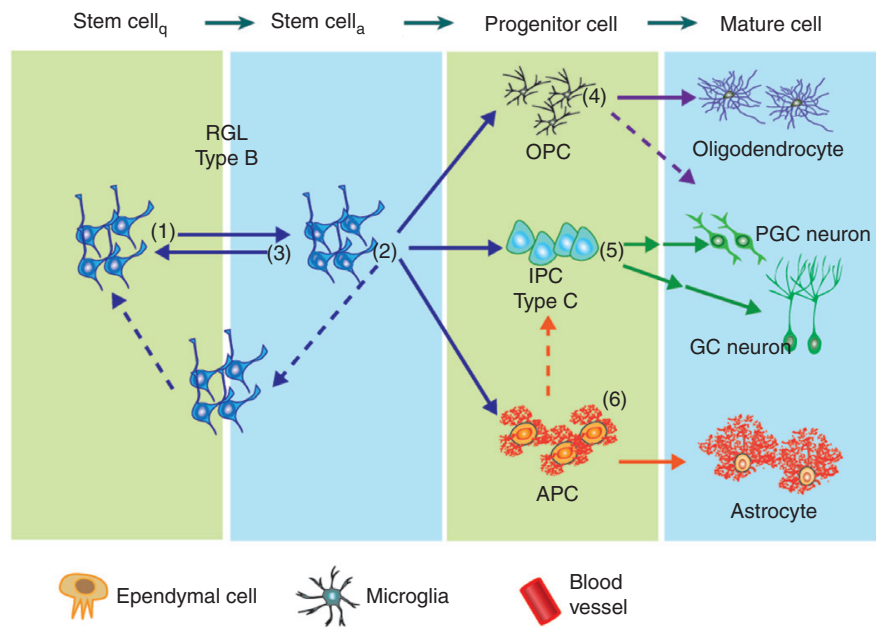

Figure 2. The stem-cell niche and lineage hierarchy among stem cells and their progeny. (A) Schematic illustration of the cell types present in the neurogenic niche of subgranular zone (SGZ) in the dentate gyrus (DG). Shown in $A^{\prime}$ is a model of the neural genesis in the adult SGZ under basal conditions. On the single-cell level, quiescent radial glia-like cells (RGLs) can become active and enter cell cycle (1). The active RGLs can generate an intermediate progenitor cell (IPC), an astrocyte progenitor cell (APC), or generate an additional RGL (2), which can become either quiescent or active. The active RGLs can remain in a proliferative state or return to quiescence (3). Nonradial, nestin ${ }^{+}$cells produce IPCs and may cycle between quiescent and active states (4). Oligodendrocyte progenitor cells (OPCs) can enter cell cycle and generate mature oligodendrocytes (5). IPCs generate excitatory granule cell (GC) neurons (6). Newborn APCs can generate mature astrocytes (7). (B) A schematic illustration of the cell types present in the neurogenic niche of the subventricular zone (SVZ). Shown in $B^{\prime}$ is a model of the neural genesis in the adult SVZ under basal conditions. On the population level (indicated by more than one cell), quiescent RGLs (type B cells) can become active and enter cell cycle (1). Progeny of active type B cells can give rise to IPCs (type C cells), APCs, and OPCs. Whether the RGLs directly make these fate choices remains unknown. RGLs may also generate additional type B cells, which could be either active or quiescent. Active type B cells can return to quiescence (3). OPCs can enter cell cycle and generate mature oligodendrocytes (4). IPCs generate classes of inhibitory neurons including periglomerular cell (PGC) and GC neurons, although it remains unclear whether the fate decisions occur within RGLs or IPCs (5). Newborn APCs can generate mature astrocytes (6). Arrows indicate direct cell generation. Dotted arrows represent potential choices requiring further experimental evidence. Double arrows represent multistep cell generation. Arrows with an X represent choices not experimentally observed. 
ological conditions (Suh et al. 2007; Jessberger et al. 2008). This has been confirmed by in vivo clonal analysis within the SGZ where it has been revealed that individual RGLs have the potential to be multipotent stem cells and divide not just asymmetrically but also symmetrically, self-renewing over a long duration (Bonaguidi et al. 2011; Song et al. 2012). Similarly, RGLs have been suggested to expand symmetrically over time at the population level (Dranovsky et al. 2011). However, alternative RGL properties have been proposed, including a lack of longterm maintenance. In one model, once activated, RGLs repeatedly enter cell cycle and generate only neurons before terminally differentiating into astrocytes (Encinas et al. 2011). Together, these findings suggest the existence of several RGL subpopulations that display varying levels of self-renewal and differentiation capacity (Bonaguidi et al. 2012). For example, RGLs labeled using different Cre drivers display discrete proliferation responses to running and antimitotic treatment, suggesting that RGLs also display functional heterogeneity (DeCarolis et al. 2013).

Evidence also implicates diversity among the radial cell pool within the radial B cells in the adult SVZ (Codega et al. 2014; Mich et al. 2014). Unlike the SGZ, B cells have the capacity for generating oligodendrocytes in addition to neurons and astrocytes in vivo (Ahn and Joyner 2005; Menn et al. 2006). However, single-cell tracing of B cells ex vivo has recently indicated that discrete $\mathrm{B}$ cells may give rise to the neuronal and oligodendroglial lineages, whereas each can also generate the astroglial lineage (Ortega et al. 2013). These results suggest that a single B cell may not be able to clonally generate all three neural cell types. Interestingly, various putative classes of B cells classes can be marked by differential expression of brain lipid-binding protein (BLBP), GFAP, epidermal growth factor receptor (EGFR), Hes5, CD133, TLX, and ID1 (Nam and Benezra 2009; Pastrana et al. 2009; Li et al. 2012; Giachino et al. 2013). It is still unclear how these molecules define radial subtypes and can represent either discrete cell types or different molecular states of a single-cell type. Whether multiple NSC types with diver- gent behaviors coexist within the adult radial population remains a fundamental question in stem-cell biology. One powerful approach to distinguish stem cells from more committed progenitors and establish cellular hierarchy is clonal analysis combined with computational modeling (Table 1) (Blanpain and Simons 2013).

Nonradial precursors have also been proposed as a stem-cell population in the adult SGZ, although their identity has not yet been described in the SVZ (Suh et al. 2007). Nonradial precursors lack any radial processes and may contain parallel extensions to the dentate granule cell layer. These precursors express Sox2, but not GFAP, and are labeled in the Hes5:gfp reporter mice (Lugert et al. 2010). They are more mitotic than RGLs, but most are not in cell cycle at any given time (Suh et al. 2007; Lugert et al. 2010). The identity and potential of nonradial precursors is not clearly delineated from early IPCs (type 2a cells), which share similar morphological and molecular characteristics and may represent an earlier state of IPCs (Kronenberg et al. 2003; Steiner et al. 2006; Lugert et al. 2010). In vivo clonal analysis indicates that RGLs can give rise to nonradial Sox $2^{+}$cells (Bonaguidi et al. 2011). Meanwhile, retrovirus-mediated lineage tracing of individual Sox $2^{+}$cells in the adult SGZ suggests limited capacity as most labeled clones exhibited limited self-renewal and unipotent differentiation, whereas no clones displayed both self-renewal and multipotentiality (Suh et al. 2007). Nonradial precursor identity, differentiation potential, and lineage relationship remain elusive and therefore require future studies using alternative lineagetracing approaches (Table 1 ).

Found in the SVZ, but not in the SGZ, ependymal cells are postulated to be a third cell type displaying NSC properties. Defined by their proximity to the lateral ventricle and function in regulating cerebrospinal fluid (CSF) motility, ependymal cells are essential niche components for neurogenesis (Sawamoto et al. 2006; PaezGonzalez et al. 2011). Ependymal cells also possess characteristic cilia and express high levels of Prominin-1/CD133 along with S100B and tubulin- $\beta$-IV (Pfenninger et al. 2007). Originally proposed as an NSC population under physio- 
M.A. Bonaguidi et al.

logical conditions, more recent studies suggest that ependymal cells contribute to neurogenesis and astrogenesis in vivo only under injury conditions, (Johansson et al. 1999; Coskun et al. 2008; Carlen et al. 2009). These results are also consistent with their role in the adult spinal cord where, on injury, ependymal cells proliferate and their progeny migrate toward the site of injury (Horner et al. 2000; Barnabe-Heider et al. 2010). Intriguingly, developmental studies suggest that ependymal cells and radial B cells derive from a common radial glia lineage and therefore may regain additional NSC behavior if given sufficient cues (Spassky et al. 2005). Ultimately, ependymal cells may represent a reserve neural stem-cell pool, although this requires further confirmation.

\section{Lineage Committed Neural Progenitor Cells}

Neural progenitor cells are generally considered to be restricted to a single lineage under physiological conditions. For example, IPCs, oligodendrocyte progenitor cells (OPCs), and astrocyte progenitor cells (APCs) generate neurons, oligodendrocytes, and astrocytes, respectively (Fig. 2). Common among them, with the possible exception of APCs, is a high level of proliferation-especially relative to NSCs (Bonaguidi et al. 2011; Costa et al. 2011; Encinas et al. 2011; Ponti et al. 2013). IPCs are the most numerous cell type in cell cycles within the adult SVZ and SGZ, and undergo $\sim 3$ divisions in both regions (Encinas et al. 2011; Ponti et al. 2013). These cells possess small tangential processes, predominately express Tbr2 in the SGZ, Mash 1 and/or Dlx 2 (type C cells) in the SVZ, and preferentially incorporate BrdU (Doetsch et al. 2002; Hodge et al. 2008; Ponti et al. 2013). Derived from both radial and nonradial precursors (Fig. 2) (Kronenberg et al. 2003; Lugert et al. 2010; Bonaguidi et al. 2011; Encinas et al. 2011), IPCs are considered transient amplifying precursors because they soon express doublecortin (DCX), a marker of committed immature neurons (Hodge et al. 2008). It remains unclear whether they can also produce astroglia or oligodendrocytes and self-renew over a long duration under basal conditions.
However, IPCs may acquire additional differentiation capacity in vivo following changes in the local environment, such as mediated by epidermal growth factor (EGF) infusion into the SVZ (Craig et al. 1996; Kuhn et al. 1997; Doetsch et al. 2002; Pastrana et al. 2009), suggesting that stemcell competence may extend into normally lineage-restricted cells.

$\mathrm{NG}_{2}{ }^{+}$oligodendrocyte progenitors constitute the major proliferative population in the adult nonneurogenic areas and are also found in substantial number in both the SVZ and SGZ (Dawson et al. 2003; Encinas et al. 2011). OPCs possess long wispy processes, express the characteristic proteogylcan NG2, as well as Olig2, platelet-derived growth factor receptor $\alpha$ (PDGFR- $\alpha$ ), and Sox10 (Zhu et al. 2011). Despite substantial debate over OPC cell potential (Belachew et al. 2003; Kang et al. 2010), the emerging consensus is that they produce astroglia and oligodendrocytes during development, but are restricted to oligodendrocyte generation in adult under physiological conditions (Fig. 2) (Zhu et al. 2011). OPCs and oligodendrocytes are generated from B cells in the SVZ, which migrate great distances into the corpus callosum, striatum, and fimbria fornix (Menn et al. 2006; Costa et al. 2011). So far, OPCs and oligodendrocytes have not been observed arising from RGLs in the adult SGZ (Fig. 2) (Bonaguidi et al. 2011), suggesting that they may represent a discrete precursor population with different embryonic origins. Nevertheless, OPCs are a dynamic cell population that can self-renew or differentiate into oligodendrocytes (Hughes et al. 2013). Remarkably, endogenous NG2 cells undergo extensive proliferation in response to various demyelinating conditions and act as a surveillance network on injury (Nait-Oumesmar et al. 1999; Menn et al. 2006; Hughes et al. 2013). Whether OPCs can also show expanded potential for cell generation under injury or other pathological conditions, as their potential role in the origin of glioma suggests, remains an interesting question (Liu et al. 2011).

Astroglia are a potential third precursor population. In the adult SGZ, these cells exhibit horizontal or bushy morphology and express GFAP, S100ß, and Aldh1l1 (Seri et al. 2004). 
Under basal conditions, astroglia are largely not considered to be a neuronal precursor cell type because they lack nestin expression and are remarkably quiescent (Steiner et al. 2004; Bonaguidi et al. 2011; Encinas et al. 2011). However, rare astroglia can be labeled with cell-cycle markers and share many immunohistological similarities with RGLs, including the neuronal determinate Ascl1 (Mash1) (Seri et al. 2004; Kim et al. 2011). Interestingly, new astroglia are also generated from RGLs in both the SGZ and SVZ and may be considered as APCs (Levison and Goldman 1993; Bonaguidi et al. 2011; Tsai et al. 2012). Whether these cells can act as transient precursors before leaving the neurogenic niche or even remain as precursors for an extended period remains to be determined (Fig. 2). Interestingly, thrombospondin 4 (Thbs 4) expression may distinguish APCs born in the adult SVZ from mature cortical astrocytes and is a necessary component of wound healing following ischemic conditions. In addition, Thbs4 removal decreases astrogenesis with a concomitant increase in neurogenesis in the SVZ (Benner et al. 2013). Because APCs have only recently been characterized in the adult brain, it will be interesting to examine their lineage capacity under physiological and nonphysiological conditions (Table 1).

\section{ORGANIZATION OF NSC DIVERSITY}

A central question in NSC biology is how their behaviors arise and this has been researched at both system and cellular levels. Computational analysis indicates that stem cells can be generally categorized as deterministic or stochastic populations (Klein and Simons 2011). Stem cells with a determined fate, such as developing Drosophila neuroblasts (Isshiki et al. 2001), possess intrinsic programming and make the same resolute divisions over time. Tissue diversity therefore arises from the coexistence of intrinsically diverse stem cells. Alternatively, stem cells displaying stochastic behavior-more common in mammalian systems, such as the developing retina (He et al. 2012) — undergo several division choices in a seemingly random manner. Stochastic decision making allows for diversity
Neural Precursors in the Adult Mammalian Brain

among individual stem cells (Simons and Clevers 2011). Although both models permit stemcell regulation at intrinsic and extrinsic levels, stochastic mechanisms confer flexibility within the stem-cell pool and endow compensatory behavior as has been observed in the postnatal SVZ (Kuo et al. 2006). Given the regionalization and patterning of the mammalian brain, examples of each model may persist from early development to serve discrete functions under physiological and pathological conditions in the adult (Chen et al. 2012).

\section{Regional Organization of Neural Precursor Cells}

A defining feature of the brain is its remarkable compartmentalization with different regions displaying specialized cell types, molecular identities, varied circuit connections, as well as contributions to different behaviors. The development of tissue specialization implies that adult NSC properties are, in part, established by neural patterning (Kriegstein and AlvarezBuylla 2009). Evidence of this principle that developmental processes may be maintained into adult neurogenic zones arises from multiple observations. Adult radial precursors are derived from radial glia of similar embryonic region suggesting that adult precursors may be remnants from development (Merkle et al. 2004; Young et al. 2007). Moreover, similar transcript factor codes that specify neural precursors in the embryonic ventricular zone are conserved into the adult SVZ (Schuurmans and Guillemot 2002; Hack et al. 2005; Young et al. 2007), where the production of certain interneuron subtypes are enriched within SVZ domains (Fig. 3) (Merkle et al. 2007; Brill et al. 2009; Ihrie and AlvarezBuylla 2011). Similarly, in the adult SVZ, astroglia arise from distinct postnatal spatial domains and undergo limited radial migration to maintain their positional fate (Tsai et al. 2012). In addition, $\mathrm{NG}^{+}$OPCs also display distinct spatial origins in the adult SVZ, preferentially arising from the dorsal SVZ compared with the lateral wall (Ortega et al. 2013). Collectively, these data suggest a model in which the SVZ displays mosaic organization not only among 
M.A. Bonaguidi et al.

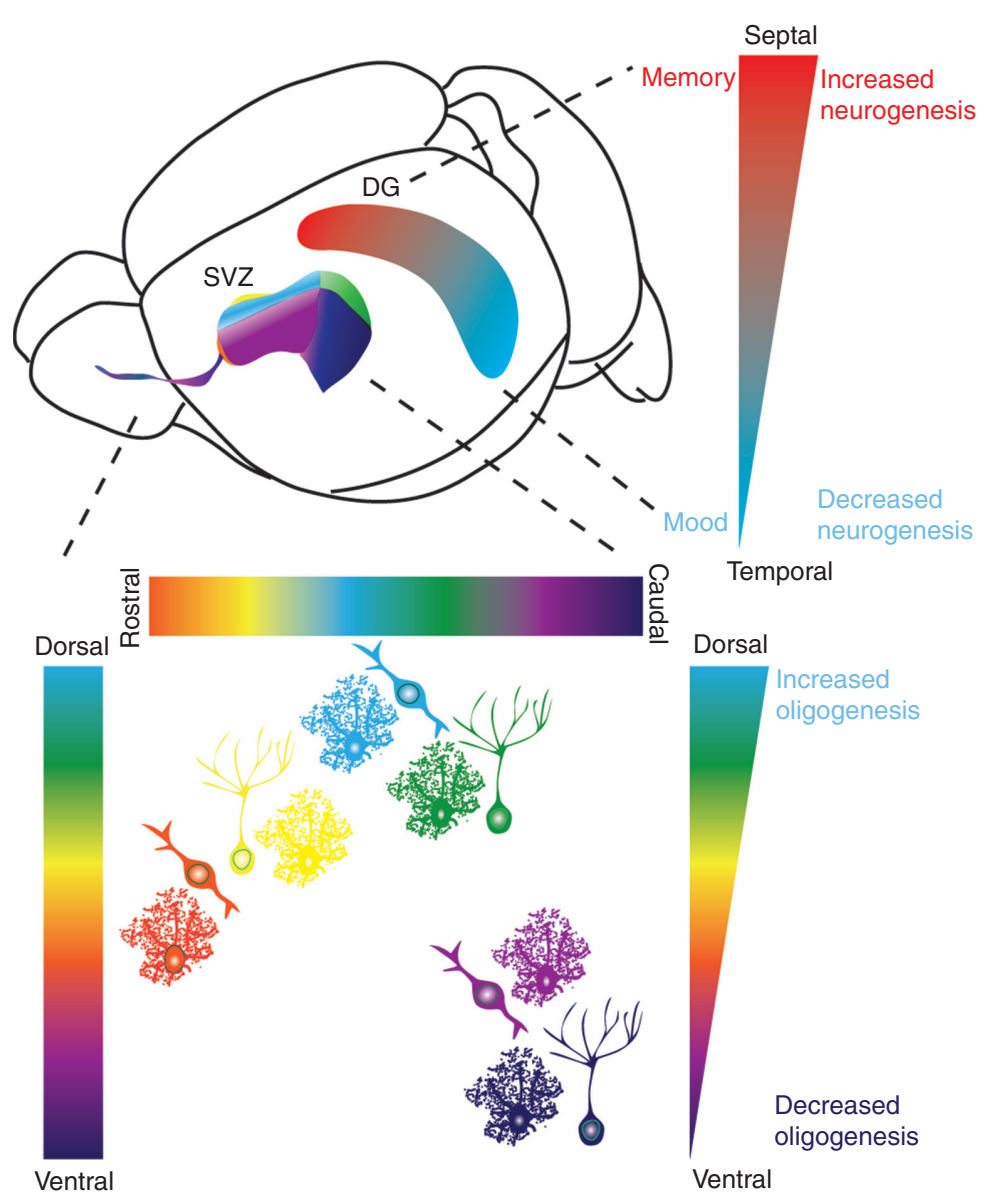

Figure 3. Regionalization of adult neural genesis in classical neurogenic zones. A schematic illustration of the mouse brain indicating the location of SVZ/RMS (subventricular zone/rostral migratory stream) and subgranular zone (SGZ) neurogenic niches. The different colors denote spatial heterogeneity of neural precursor cells. Precursor cells within the SVZ generate different interneuron subtypes, granule cells (GCs) or pergriglomerular ( periglomerular cells [PGCs]; see Fig. 2). Studies have further divided these cell types in which precursor cells originating from the ventral SVZ generate deep granule cell (purple) and calbindin-expressing periglomerular cells (magenta). Precursor cells from the dorsal SVZ on the other hand, generate superficial granule cells (green) and $\mathrm{TH}^{+}$periglomerular cells (light blue), whereas precursor cells in the medial parts of the ventricular wall generate calretinin-expressing superficial granule cells (yellow) and periglomerular cells (orange). Contrary to spatial heterogeneity and migration of long distances of neuron subtypes, astrocytes are generated throughout the SVZ and migrate more locally. Oligodendrogenesis is higher in the dorsal SVZ compared with the lateral and ventral SVZ. As schematically illustrated, the septal part of the dentate gyrus (DG) is associated with memory, has higher neurogenesis within the SGZ compared with the temporal part, which in turn has lower neurogenesis and is associated with mood regulation.

adult neurogenesis, but also astrogenesis and oligogenesis (Fig. 3).

Regionalization of NSCs in the adult SGZ is an emerging model. Differences in neural connectivity and behavior along the longitudinal (septotemporal) axis of the hippocampus are well documented (Fanselow and Dong 2010; $\mathrm{Wu}$ et al. 2015). The septal (dorsal) portion is preferentially engaged in cognitive process of learning and memory, whereas the temporal (ventral) hippocampus is associated with motivational and emotional behavior. Moreover, 
A Stem cell $\mathrm{q}_{\mathrm{a}} \longrightarrow$ Stem cell $\mathrm{a} \longrightarrow$ Progenitor cell $\longrightarrow$ Mature cell

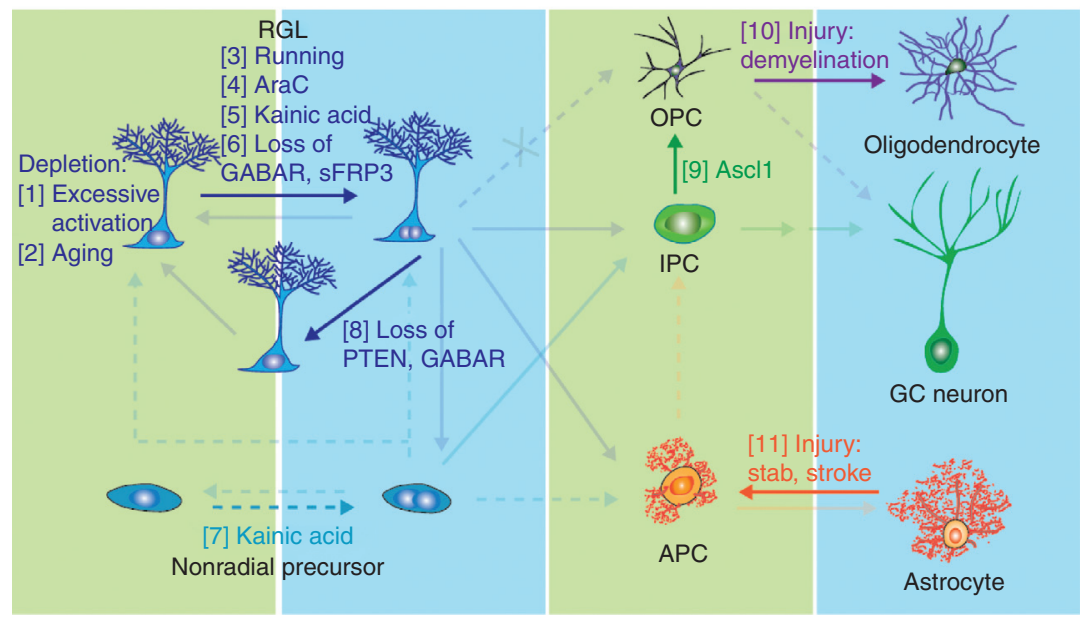

B Stem cell $\mathrm{q}_{\mathrm{a}} \longrightarrow$ Stem cell ${ }_{\mathrm{a}} \longrightarrow$ Progenitor cell $\longrightarrow$ Mature cell

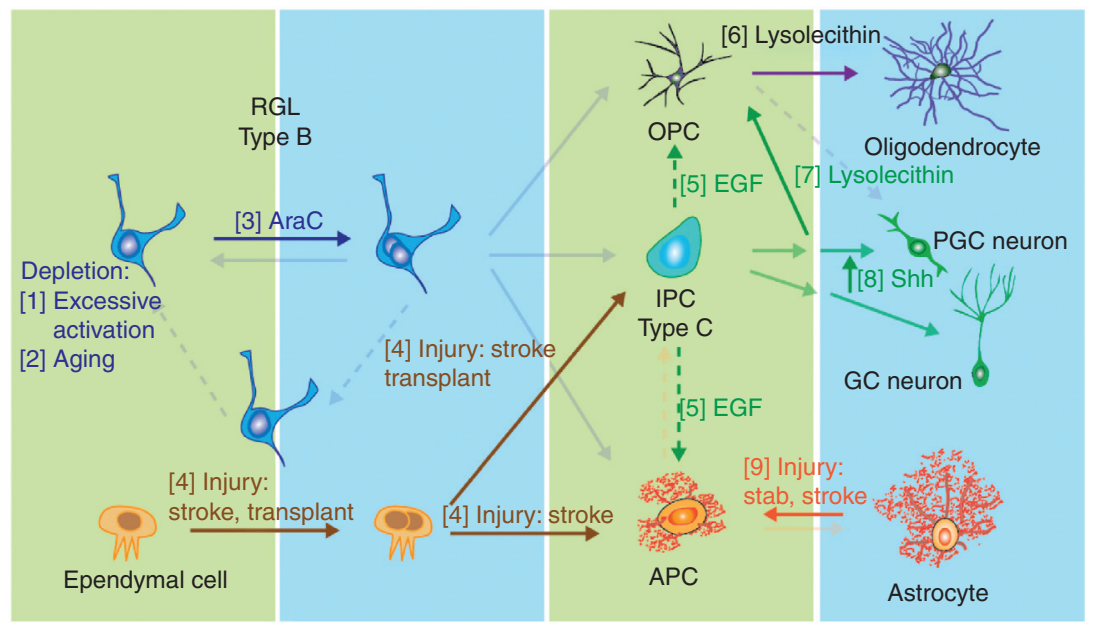

Figure 4. Regulation of neural precursor plasticity within the classical neurogenic zones. Schematic illustration of example factors and manipulations known to regulate cell genesis in the adult subgranular zone (SGZ) $(A)$ and subventricular zone $(\mathrm{SVZ})(B)$. Numbers denote examples known to affect lineage decisions at the stage indicated in the figure. $(A)$ Stem-cell loss occurs when their proliferation is highly induced, such as through Notch and FoxO deletion (1) (Paik et al. 2009; Renault et al. 2009; Ehm et al. 2010; Imayoshi et al. 2010), or in aged mice (2) (Kuhn et al. 1996; Encinas et al. 2011; Villeda et al. 2011). Mobilization of quiescent radial glia-like cells (RGLs) occurs during voluntary running (3) (Kempermann et al. 1997; van Praag et al. 1999); brain injury, such as injection of the antimitotic drug Ara-C (Seri et al. 2001) (4) or seizure-inducing Kainic acid (5) (Steiner et al. 2008; Jiruska et al. 2013). Molecular inhibitors of RGL activation include SFRP3 and GABA signaling (6) (Song et al. 2012; Jang et al. 2013). Kainic acid-induced seizures activate nonradial progenitor cells (7) (Lugert et al. 2010). Increasing Akt signaling or decreasing tonic GABA signaling alters the division mode of RGLs, fostering the symmetric fate (8) (Bonaguidi et al. 2011; Song et al. 2012). Ectopic expression of Ascl1 changes the fate of intermediate progenitor cells (IPCs) to generate oligodendrocyte progenitor cells (OPCs) (9) (Jessberger et al. 2008) and demyelination injury induces OPC proliferation (10) (Nait-Oumesmar et al. 1999; Menn et al. 2006; Hughes et al. 2013). Stab wound, stroke and ischemic injuries activate astrocytes into reactive astroglia (11) (reviewed in Robel et al. 2011). (B) In the SVZ excessive activation (1) (Paik et al. 2009; Renault et al. 2009; Ehm et al. 2010; Imayoshi et al. 2010) and aging (2) (Kuhn et al. 1996; Molofsky et al. 2006; Villeda et al. 2011) leads to stem-cell loss. Ara-C promotes RGL cell-cycle entry (3) (Doetsch et al. 1999) and stroke injury activates the normally quiescent ependymal cells (4) (Johansson et al. 1999; Coskun et al. 2008; Carlen et al. 2009). Infusion of EGF increases production of astroglia and OPCs while reducing proliferation of IPCs (5) (Craig et al. 1996; Kuhn et al. 1997). Demyelination injury increases OPC proliferation (6) and doublecortin (DCX) ${ }^{+}$neural progenitors to swich fate into OPCs (7) (Nait-Oumesmar et al. 1999; Menn et al. 2006; Jablonska et al. 2010; Hughes et al. 2013). Manipulation of the Sonic hedgehog ( $\mathrm{SHH}$ ) signaling pathway can change the fate of a subset of neural progenitors from granule cell (GC) neurons to periglomerular cell (PGC) neurons (8) (Ihrie et al. 2011). Stab wound, stroke, and ischemic injuries activate astrocytes into reactive astroglia (9) (reviewed in Robel et al. 2011). 
M.A. Bonaguidi et al.

detailed gene expression supports a segregation of the hippocampus and the SGZ in particular into septal, temporal, and intermediate zones (Fanselow and Dong 2010). Interestingly, adult neurogenesis is not uniform throughout the SGZ, with fewer neural precursors in the temporal DG (Fig. 3) (Tashiro et al. 2007; Jinno 2011a). Meanwhile, the tempo of neurogenesis is slower in the temporal region compared with the septal region and behaves differently to neuronal activity and aging (Jinno 2011b; Piatti et al. 2011; Snyder et al. 2012). Dentate formation arises from distinct developmental locations within the septotemporal plane (Altman and Bayer 1990) and from the temporal pole of the ventral hippocampus (Li et al. 2013) implicating mosaic spatial patterning as a putative mechanism underlying adult SGZ neural precursor diversity.

The relative contribution of intrinsic and extrinsic cues in conferring divergent adult neural precursor behavior is starting to emerge. When neural precursors are put in cell culture or transplanted across SVZ regions, interneuron subtype generation remains the same as the region of origin (Merkle et al. 2007). These observations are consistent with a timed program encoded, at least in part, by intrinsic factors (Qian et al. 2000). Meanwhile, changes in extrinsic cues are also instructive of cell fate decisions. Ectopic activation of Sonic hedgehog signaling (Shh) is sufficient to respecify dorsally derived interneuron progeny to more ventrally defined fates (Ihrie et al. 2011). Additional examples of cell fate alteration by extrinsic regulation occur in the SGZ. RGLs that normally undergo asymmetric neuronal and astroglial cell division instead preferentially divide symmetrically on increasing Akt signaling or decreasing tonic GABA signaling (Song et al. 2012). Therefore, it appears that intrinsic cues prime cell fate, whereas extrinsic cues can modulate that program, a model consistent with stochastic asymmetry regulation of stem-cell behavior.

Local Organization within Neurogenic Regions

Further local organization of neural precursor cells may allow for diverse individual stem-cell behavior and coexistence of neural precursor populations. First suggested within the hematopoietic system (Schofield 1978), the niche is a microenvironment that houses and supports stem-cell behavior and largely restricts high levels of adult mammalian neurogenesis to the SVZ and SGZ under basal conditions (Riquelme et al. 2008; Fuentealba et al. 2012). The niche constituents can also promote neural precursor diversity (Fig. 3). Vasculature, astroglia, microglia, ependymal cells, and neural precursor subtypes create niche microdomains. Dynamic access to these components can influence NSC decisions, such as radial cell contact with vasculature mediating a switch between quiescence and proliferation (Palmer et al. 2000; Mirzadeh et al. 2008; Shen et al. 2008; Tavazoie et al. 2008). These associations could also serve as an attractant for more proliferative precursors and potentially a hotspot for discrete mitotic stemcell populations. In addition, cells present throughout the adult brain can have different functions within the niche. Astroglia within the adult SVZ and SGZ have the unique capability to promote neurogenic fate specification, neuroblast migration, and survival (Lim and Alvarez-Buylla 1999; Song et al. 2002; Barkho et al. 2006; Kaneko et al. 2010; Platel et al. 2010). As astroglia remain local to their region of origin (Fig. 3) (Tsai et al. 2012), it remains unclear whether subpopulations of astroglia within the niche exhibit specialized functions and whether such heterogeneity could further diversify neural precursor cells (Zhang and Barres 2010).

The role of cellular components within the niche can also change depending on the environment. For instance, microglia normally phagocytose and remove dying IPCs (Sierra et al. 2010) and can, within different contexts, have either a beneficial or detrimental effect on neural precursor development (Ekdahl et al. 2009). Likewise, the composition of the CSF secretome is altered on various physiological and pathological conditions (reviewed in Falcao et al. 2012; Zappaterra and Lehtinen 2012). Given that many extrinsic cues, including growth factors, neurotransmitters, cytokines, and hormones, change during injury (reviewed in Zhao et al. 2008), the state of the local environment itself 
can determine neural precursor diversity. An important function of these niche factors under physiological conditions is to maintain NSC quiescence, as excessive NSC activation can lead to impaired NSC maintenance (Paik et al. 2009; Renault et al. 2009; Ehm et al. 2010; Imayoshi et al. 2010). The neuronal circuit itself may act in this manner where interneurons and mature dentate granule neurons in the SGZ repress RGL activation through tonic GABA signaling and the WNTantagonist secreted frizzled related protein 3 (sFRP3), respectively (Song et al. 2012; Jang et al. 2013). These mechanisms act far reaching (GABA) or locally (sFRP3) to fine-tune stem-cell response to environmental change. How neural network activity controls stem-cell behavior directly or indirectly through the niche is an emerging area of research.

Moreover, coordination among the cellular constituents within the niche likely also contributes to homeostasis. For example, elimination of IPCs/neuroblasts causes activation of the quiescent radial cells, which rapidly repopulate IPCs (Doetsch et al. 1999; Seri et al. 2001). The feedback mechanisms from IPCs/neuroblasts to radial precursor cells could include GABA or Notch signaling (Liu et al. 2005; Basak et al. 2012) and suggests that NSC descendants are active constituents of the adult niche. As IPCs and neuroblasts are transient in nature, their waxing and waning provides another layer of local dynamics within the niche. Ultimately, these principles provide a collective context for how local cellular cues can promote individual NSC diversity.

\section{REGULATION OF ADULT NEURAL PRECURSOR CELL PLASTICITY}

A hallmark of neurogenesis in the adult brain is its sensitivity to external changes. Environmental or pathological alterations can have stagespecific effects on precursor proliferation, cell migration, cell death, neuronal maturation, and circuit integration (Zhao et al. 2008). Less well studied are the roles of extrinsic cues on specific neural precursor types and how precursor plasticity adjusts to meet shifting tissue de-
Neural Precursors in the Adult Mammalian Brain

mands. An emerging general theme across multiple somatic-stem-cell compartments is the coexistence of precursor cell populations for differential responses to physiological and injury conditions (Leung et al. 2007; Wilson et al. 2008; Li and Clevers 2010; Lu et al. 2012; Mascre et al. 2012; Buczacki et al. 2013). Technical advances in neural precursor cell-type identification, lineage tracing, and cell-type-specific manipulation provide an opportunity to reveal the cellular and molecular substrates of external changes beyond describing general cell proliferation (Table 1). Indeed, recent studies suggest that diverse neural precursor cells also exhibit differential responses to the environment under physiological or pathological conditions (Lugert et al. 2010; DeCarolis et al. 2013).

\section{Physiological Regulation of Neural Precursor Plasticity}

Adult neurogenesis is influenced by many physiological stimuli including exercise, environmental enrichment (EE), social isolation, aging, and learning paradigms (reviewed in Ming and Song 2011). The exact neural precursor targets of these experiences are largely unknown, but general principles are beginning to emerge. From studies of the SGZ, it appears that experience can dictate the properties of neural precursors. For example, running either alone or as a component of EE has been long known to promote neurogenesis (Kempermann et al. 1997; van Praag et al. 1999; Steiner et al. 2008; Kobilo et al. 2011; Mustroph et al. 2012). Although the hippocampal IPC cell populations increase after running, this may be a result of mobilizing quiescent RGLs (Kronenberg et al. 2003; Lugert et al. 2010). Curiously, the effect of running is observed in $\mathrm{Hes}^{+}$and not Nestin::GFP ${ }^{+}$RGLs suggesting functional heterogeneity within the radial cell population (Kronenberg et al. 2003; Steiner et al. 2008; Lugert et al. 2010). It remains unclear whether running also facilitates a fate switch of RGLs from glial to neuronal production. Appealing candidates to mediate the effect include Wnt, bone morphogenetic protein (BMP), and brain-derived neurotropic factor (BDNF) signaling (Rossi et al. 2006; Gobeske 
M.A. Bonaguidi et al.

et al. 2009; Jang et al. 2013). Conversely, social stress or glucocorticoids have profound negative effects on neurogenesis and cell genesis has a role in efficient stress recovery (Dranovsky and Hen 2006; Stranahan et al. 2006; Snyder et al. 2011). In addition to decreasing neurogenesis, social isolation in juvenile mice promotes expansion of the adult RGL population (Dranovsky et al. 2011). This expansion occurs through increased RGL activation and a switch from asymmetric to symmetric divisions via tonic GABA signaling (Song et al. 2012). Together, results from exercise and social isolation experiments suggest another emerging principle: environmental. Environmental factors can have positive and negative effects on neurogenesis, partially through targeting the NSC populations.

Aging studies provide another platform to investigate mechanisms regulating neural precursor behavior because neurogenesis strongly declines as a rodent ages (Kuhn et al. 1996). This decline in both SGZ and SVZ neurogenesis is thought to result from the loss of stem cells, including the radial precursors (Molofsky et al. 2006; Encinas et al. 2011; Villeda et al. 2011). Interestingly, RGLs in the SGZ do not appear to change their proliferation activity with age (Encinas et al. 2011; but see Hattiangady and Shetty 2008). Instead, changes in the niche may underlie the decrease in neural precursor number. One experimental approach used to test niche contribution is parabiosis, in which the blood systems of two mice are surgically combined. Remarkably, old mice paired with young mice show an increase in the number of immature neurons in the DG, whereas the opposite is seen in the young mice in the same pair (Conboy et al. 2013). This result is associated with the age-dependent increase in chemokines, such as eotaxin (Villeda et al. 2011). In addition, physiological activity, such as EE and running, also increase proliferation in aged mice, although the mechanisms are unclear (Kempermann et al. 1998). These data suggest that a decline in neural precursor number with age may be partially ameliorated by altering the aged cellular niche, and it will be important to understand the cellular and molecular niche involved in aging.
Pathological Regulation of Precursor Plasticity

Neurogenesis in the adult brain has also been investigated in response to numerous pathological conditions including seizures, cytosine$\beta$-D-arabinofuranoside (Ara-C) injury, stab wound injury, traumatic brain injury (TBI), stroke, psychological disorders, and neurodegenerative diseases. A common theme among injury studies is that, unlike lower vertebrates, such as fish and amphibians, mammals do not significantly repair damaged neuronal tissue (Berg et al. 2010; Zupanc and Sirbulescu 2011; Illis 2012). Repair in mammals appears limited by deficits in neuronal maturation and survival, (Kokaia et al. 2006; Kazanis et al. 2013; although see Magavi et al. 2000) and can be initially robust in both the SVZ and SGZ (Liu et al. 1998; Arvidsson et al. 2002; Parent et al. 2002). Importantly, production of astroglia and neuroblasts contributes to minimizing initial damage during injury, suggesting an essential role of cell genesis in buffering the brain from a more severe insult (Jin et al. 2010; Benner et al. 2013). Increased proliferation is observed on many injury models, even in areas that are not neurogenic under physiological conditions (Magavi et al. 2000; Chen et al. 2004). At present, the precise cellular and molecular events mediating diverse precursor behavior under pathological conditions have not been explored extensively.

A general premise to describe the neurogenic response to injury may be that the severity of an injury or acute pathological condition determines the magnitude of the initial neural precursor response. In less severe conditions, such as AraC and epilepsy, NSCs are recruited in attempts to promote homeostasis. For example, the antimitotic drug Ara-C has been used to study regeneration of neurogenic populations in the adult brain. Because Ara-C treatment primarily kills the proliferating IPCs, quiescent radial precursor cells were identified as cellular origins of neural precursor recovery in both the SVZ and SGZ (Doetsch et al. 1999; Seri et al. 2001). Intriguingly, RGLs labeled using different Cre drivers selectively proliferate on antimitotic treatment indicating that neural precursors with similar identity can display 
functional heterogeneity (DeCarolis et al. 2013). In addition, epilepsy and seizures are known to affect many aspect of adult neurogenesis, including proliferation of neural precursor cells and the migration pattern of immature neurons (Parent et al. 1997). Injection of seizure-inducing substances, such as kainic acid and pilocarpine have a proproliferative effect on radial cells, IPCs, and neuroblasts (Steiner et al. 2008; Jiruska et al. 2013). Interestingly, kainic acid increases the size of the nonradial, but not radial, precursor pool, suggesting that neural precursors of different identities can display diverse response to a common injury (Lugert et al. 2010). Yet an unanswered question is whether radial and nonradial cells change their basal stem-cell properties on injury.

Greater cell plasticity appears to occur on more severe injury, such as TBI and stroke. For instance, ependymal cells have been observed to change their morphology radial glial-like shape after stroke (Zhang et al. 2007). Normally, quiescent ependymal cells activate and generate both astrocytes and neuroblasts suggesting that they might act as a reservoir stem-cell population (Zhang et al. 2007; Carlen et al. 2009). Astrocytes represent a second cell population displaying enhanced cell plasticity after injury. In response to a stab wound or cerebral ischemia, astrocytes can become reactive and display NSC markers including nestin, vimentin, and BLBP (Robel et al. 2011). Reactive astroglia remain restricted to gliogenesis in vivo, yet become primed to behave as NSCs on exposure to growth factors in vitro, whereas astrocytes under basal conditions do not (Buffo et al. 2008; Sirko et al. 2013). Astrocytes are a heterogeneous population of cells, and it is not known whether diverse populations of astrocytes react differently to the various types of injury (Zhang and Barres 2010). In vivo imaging has revealed that astrocytes found in close proximity to vasculature proliferate in response to a stab wound injury (Bardehle et al. 2013). Perhaps the greatest example of neural precursor injury-induced plasticity in the adult mammalian brain is the fate switch of $\mathrm{DCX}^{+}$neuroblasts in the rostral migratory stream (RMS). Lysolecithin-induced demyelination of corpus callosum redirects
Neural Precursors in the Adult Mammalian Brain

$\mathrm{DCX}^{+}$progenitors from neuronal to glial fates to generate new oligodendrocytes in the corpus callosum (Jablonska et al. 2010). However, changes in neural precursor developmental potential do not appear to be sufficient to significantly repair damaged neuronal tissue and may require additional plasticity, such as in vivo reprogramming (Jessberger et al. 2008; Niu et al. 2013).

\section{CONCLUSIONS}

Diverse origins of cell genesis is an emerging principle in many adult somatic tissues, which can display differences among precursor identity, potential, and regulation (Alvarez-Buylla et al. 2008; Li and Clevers 2010). A common theme among different somatic systems is the coexistence of multiple precursor cells within a tissue to satisfy particular local demands. Neural stem and progenitor cells take multiple forms in the adult brain: from radial to nonradial precursor cells; lineage-restricted neuronal, astroglial, and oligodendroglial progenitors; and ependymal cells. Further, diversity may also exist within neural precursors of similar cellular identity. Recent data indicates that cellular hierarchy exists among cell types under physiological conditions. Meanwhile, neural precursor competence is partially conferred through cellular interactions, both locally within the niche and patterning across various spatial domains. Finally, dormant plasticity among diverse cell types can be unleashed during pathological response or by genetic alterations. These studies collectively suggest that a diverse range of neural precursors are organized to collectively meet the dynamic needs of specialized remodeling functions. Future investigations should take into account the diversity of cell types to understand how the adult brain undergoes dynamic remodeling to mediate an individual's interactions with the outside world.

\section{ACKNOWLEDGMENTS}

The authors thank G. Sun and K. Christian for critically evaluating this manuscript. Research in the authors' laboratories is supported by 
M.A. Bonaguidi et al.

the Brain \& Behavior Research Foundation (NARSAD) (J.S., G.-1.M.), Simons Foundation Autism Research Initiative (SFARI) (H.S.), National Institutes of Health ([NIH] NS080913 to M.A.B.; NS048271, HD069184 to G.-1.M.; S047344, ES021957 to H.S.), the Dr. Miriam and Sheldon G. Adelson Medical Research Foundation (G.-1.M.), Maryland Stem Cell Research Fund (G.-1.M.), and European Molecular Biology Organization (EMBO) long-term fellowship (D.A.B.). The authors acknowledge the joint participation by the Diana Helis Henry Medical Research Foundation through its direct engagement in the continuous active conduct of medical research in conjunction with The Johns Hopkins Hospital and the Johns Hopkins University School of Medicine and the Foundation's Parkinson's Disease Program No. H-1 (to G.-1.M.).

\section{REFERENCES}

${ }^{*}$ Reference is also in this collection.

Ahn S, Joyner AL. 2005. In vivo analysis of quiescent adult neural stem cells responding to Sonic hedgehog. Nature 437: 894-897.

Altman J, Bayer SA. 1990. Migration and distribution of two populations of hippocampal granule cell precursors during the perinatal and postnatal periods. J Comp Neurol 301: 365-381.

Alvarez-Buylla A, Kohwi M, Nguyen TM, Merkle FT. 2008. The heterogeneity of adult neural stem cells and the emerging complexity of their niche. Cold Spring Harb Symp Quant Biol 73: 357-365.

Arvidsson A, Collin T, Kirik D, Kokaia Z, Lindvall O. 2002. Neuronal replacement from endogenous precursors in the adult brain after stroke. Nat Med 8: 963-970.

Bardehle S, Kruger M, Buggenthin F, Schwausch J, Ninkovic J, Clevers H, Snippert HJ, Theis FJ, Meyer-Luehmann M, Bechmann I, et al. 2013. Live imaging of astrocyte responses to acute injury reveals selective juxtavascular proliferation. Nat Neurosci 16: 580-586.

Barkho BZ, Song H, Aimone JB, Smrt RD, Kuwabara T, Nakashima K, Gage FH, Zhao X. 2006. Identification of astrocyte-expressed factors that modulate neural stem/ progenitor cell differentiation. Stem Cells Dev 15: 407421.

Barnabe-Heider F, Goritz C, Sabelstrom H, Takebayashi H, Pfrieger FW, Meletis K, Frisen J. 2010. Origin of new glial cells in intact and injured adult spinal cord. Cell Stem Cell 7: 470-482.

Basak O, Giachino C, Fiorini E, Macdonald HR, Taylor V. 2012. Neurogenic subventricular zone stem/progenitor cells are Notch1-dependent in their active but not quiescent state. J Neurosci 32: 5654-5666.
Belachew S, Chittajallu R, Aguirre AA, Yuan X, Kirby M, Anderson S, Gallo V. 2003. Postnatal NG2 proteoglycanexpressing progenitor cells are intrinsically multipotent and generate functional neurons. J Cell Biol 161: 169186.

Benner EJ, Luciano D, Jo R, Abdi K, Paez-Gonzalez P, Sheng H, Warner DS, Liu C, Eroglu C, Kuo CT. 2013. Protective astrogenesis from the SVZ niche after injury is controlled by Notch modulator Thbs4. Nature 497: 369-373.

Berg DA, Kirkham M, Beljajeva A, Knapp D, Habermann B, Ryge J, Tanaka EM, Simon A. 2010. Efficient regeneration by activation of neurogenesis in homeostatically quiescent regions of the adult vertebrate brain. Development 137: 4127-4134.

Blanpain C, Simons BD. 2013. Unravelling stem cell dynamics by lineage tracing. Nat Rev Mol Cell Biol 14: 489-502.

Bonaguidi MA, Wheeler MA, Shapiro JS, Stadel RP, Sun GJ, Ming GL, Song H. 2011. In vivo clonal analysis reveals self-renewing and multipotent adult neural stem cell characteristics. Cell 145: 1142-1155.

Bonaguidi MA, Song J, Ming GL, Song H. 2012. A unifying hypothesis on mammalian neural stem cell properties in the adult hippocampus. Curr Opin Neurobiol 22: 754761.

Brill MS, Ninkovic J, Winpenny E, Hodge RD, Ozen I, Yang R, Lepier A, Gascon S, Erdelyi F, Szabo G, et al. 2009. Adult generation of glutamatergic olfactory bulb interneurons. Nat Neurosci 12: 1524-1533.

Buczacki SJ, Zecchini HI, Nicholson AM, Russell R, Vermeulen L, Kemp R, Winton DJ. 2013. Intestinal labelretaining cells are secretory precursors expressing Lgr5. Nature 495: 65-69.

Buffo A, Rite I, Tripathi P, Lepier A, Colak D, Horn AP, Mori T, Gotz M. 2008. Origin and progeny of reactive gliosis: A source of multipotent cells in the injured brain. Proc Natl Acad Sci 105: 3581-3586.

Carlen M, Meletis K, Goritz C, Darsalia V, Evergren E, Tanigaki K, Amendola M, Barnabe-Heider F, Yeung MS Naldini L, et al. 2009. Forebrain ependymal cells are Notch-dependent and generate neuroblasts and astrocytes after stroke. Nat Neurosci 12: 259-267.

Chen J, Magavi SS, Macklis JD. 2004. Neurogenesis of corticospinal motor neurons extending spinal projections in adult mice. Proc Natl Acad Sci 101: 16357-16362.

Chen Z, Li X, Desplan C. 2012. Deterministic or stochastic choices in retinal neuron specification. Neuron 75: 739742.

Codega P, Silva-Vargas V, Paul A, Maldonado-Soto AR, Deleo AM, Pastrana E, Doetsch F. 2014. Prospective identification and purification of quiescent adult neural stem cells from their in vivo niche. Neuron 82: 545-559.

Conboy MJ, Conboy IM, Rando TA. 2013. Heterochronic parabiosis: Historical perspective and methodological considerations for studies of aging and longevity. Aging Cell 12: 525-530.

Coskun V, Wu H, Blanchi B, Tsao S, Kim K, Zhao J, Biancotti JC, Hutnick L, Krueger RC Jr, Fan G, et al. 2008. CD133 neural stem cells in the ependyma of mammalian postnatal forebrain. Proc Natl Acad Sci 105: 1026-1031.

Costa MR, Ortega F, Brill MS, Beckervordersandforth R, Petrone C, Schroeder T, Gotz M, Berninger B. 2011. Con- 
tinuous live imaging of adult neural stem cell division and lineage progression in vitro. Development 138: 10571068.

Craig CG, Tropepe V, Morshead CM, Reynolds BA, Weiss S, van der Kooy D. 1996. In vivo growth factor expansion of endogenous subependymal neural precursor cell populations in the adult mouse brain. J Neurosci 16: 26492658.

Dawson MR, Polito A, Levine JM, Reynolds R. 2003. NG2expressing glial progenitor cells: An abundant and widespread population of cycling cells in the adult rat CNS. Mol Cell Neurosci 24: 476-488.

DeCarolis NA, Mechanic M, Petrik D, Carlton A, Ables JL, Malhotra S, Bachoo R, Gotz M, Lagace DC, Eisch AJ. 2013. In vivo contribution of nestin- and GLAST-lineage cells to adult hippocampal neurogenesis. Hippocampus 23: 708-719.

Doetsch F, Caille I, Lim DA, Garcia-Verdugo JM, AlvarezBuylla A. 1999. Subventricular zone astrocytes are neural stem cells in the adult mammalian brain. Cell 97: 703716.

Doetsch F, Petreanu L, Caille I, Garcia-Verdugo JM, AlvarezBuylla A. 2002. EGF converts transit-amplifying neurogenic precursors in the adult brain into multipotent stem cells. Neuron 36: 1021-1034.

Dranovsky A, Hen R. 2006. Hippocampal neurogenesis: Regulation by stress and antidepressants. Biol Psychiatry 59: 1136-1143.

Dranovsky A, Picchini AM, Moadel T, Sisti AC, Yamada A, Kimura S, Leonardo ED, Hen R. 2011. Experience dictates stem cell fate in the adult hippocampus. Neuron 70: 908-923.

Ehm O, Goritz C, Covic M, Schaffner I, Schwarz TJ, Karaca E, Kempkes B, Kremmer E, Pfrieger FW, Espinosa L, et al. 2010. RBPJк-dependent signaling is essential for longterm maintenance of neural stem cells in the adult hippocampus. J Neurosci 30: 13794-13807.

Ekdahl CT, Kokaia Z, Lindvall O. 2009. Brain inflammation and adult neurogenesis: The dual role of microglia. $\mathrm{Neu}$ roscience 158: 1021-1029.

Encinas JM, Michurina TV, Peunova N, Park JH, Tordo J, Peterson DA, Fishell G, Koulakov A, Enikolopov G. 2011. Division-coupled astrocytic differentiation and age-related depletion of neural stem cells in the adult hippocampus. Cell Stem Cell 8: 566-579.

Falcao AM, Marques F, Novais A, Sousa N, Palha JA, Sousa JC. 2012. The path from the choroid plexus to the subventricular zone: Go with the flow! Front Cell Neurosci 6: 34.

Fanselow MS, Dong HW. 2010. Are the dorsal and ventral hippocampus functionally distinct structures? Neuron 65: 7-19.

Fuentealba LC, Obernier K, Alvarez-Buylla A. 2012. Adult neural stem cells bridge their niche. Cell Stem Cell 10: 698-708.

Gabay L, Lowell S, Rubin LL, Anderson DJ. 2003. Deregulation of dorsoventral patterning by FGF confers trilineage differentiation capacity on CNS stem cells in vitro. Neuron 40: 485-499.

Gage FH. 2000. Mammalian neural stem cells. Science 287: $1433-1438$.
Garcia AD, Doan NB, Imura T, Bush TG, Sofroniew MV. 2004. GFAP-expressing progenitors are the principal source of constitutive neurogenesis in adult mouse forebrain. Nat Neurosci 7: 1233-1241.

Giachino C, Basak O, Lugert S, Knuckles P, Obernier K, Fiorelli R, Frank S, Raineteau O, Alvarez-Buylla A, Taylor V. 2013. Molecular diversity subdivides the adult forebrain neural stem cell population. Stem Cells 32: 70-84.

Gobeske KT, Das S, Bonaguidi MA, Weiss C, Radulovic J, Disterhoft JF, Kessler JA. 2009. BMP signaling mediates effects of exercise on hippocampal neurogenesis and cognition in mice. PLoS ONE 4: e7506.

Hack MA, Saghatelyan A, de Chevigny A, Pfeifer A, AsheryPadan R, Lledo PM, Gotz M. 2005. Neuronal fate determinants of adult olfactory bulb neurogenesis. Nat Neurosci 8: $865-872$.

Hattiangady B, Shetty AK. 2008. Aging does not alter the number or phenotype of putative stem/progenitor cells in the neurogenic region of the hippocampus. Neurobiol Aging 29: 129-147.

He J, Zhang G, Almeida AD, Cayouette M, Simons BD, Harris WA. 2012. How variable clones build an invariant retina. Neuron 75: 786-798.

Hodge RD, Kowalczyk TD, Wolf SA, Encinas JM, Rippey C, Enikolopov G, Kempermann G, Hevner RF. 2008. Intermediate progenitors in adult hippocampal neurogenesis: Tbr2 expression and coordinate regulation of neuronal output. J Neurosci 28: 3707-3717.

Horner PJ, Power AE, Kempermann G, Kuhn HG, Palmer TD, Winkler J, Thal LJ, Gage FH. 2000. Proliferation and differentiation of progenitor cells throughout the intact adult rat spinal cord. J Neurosci 20: 2218-2228.

Hughes EG, Kang SH, Fukaya M, Bergles DE. 2013. Oligodendrocyte progenitors balance growth with self-repulsion to achieve homeostasis in the adult brain. Nat Neurosci 16: 668-676.

Ihrie RA, Alvarez-Buylla A. 2011. Lake-front property: A unique germinal niche by the lateral ventricles of the adult brain. Neuron 70: 674-686.

Ihrie RA, Shah JK., Harwell C.C., Levine J.H., Guinto C.D., Lezameta M., Kriegstein A.R., Alvarez-Buylla A. 2011. Persistent sonic hedgehog signaling in adult brain determines neural stem cell positional identity. Neuron 71: $250-262$.

Illis LS. 2012. Central nervous system regeneration does not occur. Spinal Cord 50: 259-263.

Imayoshi I, Sakamoto M, Yamaguchi M, Mori K, Kageyama R. 2010. Essential roles of Notch signaling in maintenance of neural stem cells in developing and adult brains. J Neurosci 30: 3489-3498.

Isshiki T, Pearson B, Holbrook S, Doe CQ. 2001. Drosophila neuroblasts sequentially express transcription factors which specify the temporal identity of their neuronal progeny. Cell 106: 511-521.

Jablonska B, Aguirre A, Raymond M, Szabo G, Kitabatake Y, Sailor KA, Ming GL, Song H, Gallo V. 2010. Chordininduced lineage plasticity of adult SVZ neuroblasts after demyelination. Nat Neurosci 13: 541-550.

Jang MH, Bonaguidi MA, Kitabatake Y, Sun J, Song J, Kang E, Jun H, Zhong C, Su Y, Guo JU, et al. 2013. Secreted frizzled-related protein 3 regulates activity-dependent 
M.A. Bonaguidi et al.

adult hippocampal neurogenesis. Cell Stem Cell 12: 215223.

Jessberger S, Toni N, Clemenson GD Jr, Ray J, Gage FH. 2008. Directed differentiation of hippocampal stem/progenitor cells in the adult brain. Nat Neurosci 11: 888-893.

Jin K, Wang X, Xie L, Mao XO, Greenberg DA. 2010. Transgenic ablation of doublecortin-expressing cells suppresses adult neurogenesis and worsens stroke outcome in mice. Proc Natl Acad Sci 107: 7993-7998.

Jinno S. 2011a. Topographic differences in adult neurogenesis in the mouse hippocampus: A stereology-based study using endogenous markers. Hippocampus 21: 467-480.

Jinno S. 2011b. Decline in adult neurogenesis during aging follows a topographic pattern in the mouse hippocampus. J Comp Neurol 519: 451-466.

Jiruska P, Shtaya AB, Bodansky DM, Chang WC, Gray WP, Jefferys JG. 2013. Dentate gyrus progenitor cell proliferation after the onset of spontaneous seizures in the tetanus toxin model of temporal lobe epilepsy. Neurobiol Dis 54: $492-498$.

Johansson CB, Momma S, Clarke DL, Risling M, Lendahl U, Frisen J. 1999. Identification of a neural stem cell in the adult mammalian central nervous system. Cell 96: 25-34.

Kaneko N, Marin O, Koike M, Hirota Y, Uchiyama Y, Wu JY, Lu Q, Tessier-Lavigne M, Alvarez-Buylla A, Okano H, et al. 2010. New neurons clear the path of astrocytic processes for their rapid migration in the adult brain. Neuron 67: $213-223$.

Kang SH, Fukaya M, Yang JK, Rothstein JD, Bergles DE. 2010. NG2 ${ }^{+}$CNS glial progenitors remain committed to the oligodendrocyte lineage in postnatal life and following neurodegeneration. Neuron 68: 668-681.

Kazanis I, Gorenkova N, Zhao JW, Franklin RJ, Modo M, Ffrench-Constant C. 2013. The late response of rat subependymal zone stem and progenitor cells to stroke is restricted to directly affected areas of their niche. Exp Neurol 248C: 387-397.

Kempermann G, Gage FH. 1999. New nerve cells for the adult brain. Sci Am 280: 48-53.

Kempermann G, Kuhn HG, Gage FH. 1997. More hippocampal neurons in adult mice living in an enriched environment. Nature 386: 493-495.

Kempermann G, Kuhn HG, Gage FH. 1998. Experienceinduced neurogenesis in the senescent dentate gyrus. $J$ Neurosci 18: 3206-3212.

Kim EJ, Ables JL, Dickel LK, Eisch AJ, Johnson JE. 2011 Ascl1 (Mash1) defines cells with long-term neurogenic potential in subgranular and subventricular zones in adult mouse brain. PLOS ONE 6: e18472.

Klein AM, Simons BD. 2011. Universal patterns of stem cell fate in cycling adult tissues. Development 138: 31033111.

Kobilo T, Liu QR, Gandhi K, Mughal M, Shaham Y, van Praag H. 2011. Running is the neurogenic and neurotrophic stimulus in environmental enrichment. Learn Mem 18: 605-609.

Kokaia Z, Thored P, Arvidsson A, Lindvall O. 2006. Regulation of stroke-induced neurogenesis in adult brain-Recent scientific progress. Cereb Cortex 16: i162-i167.
Kondo T, Raff M. 2000. Oligodendrocyte precursor cells reprogrammed to become multipotential CNS stem cells. Science 289: 1754-1757.

Kretzschmar K, Watt FM. 2012. Lineage tracing. Cell 148: 33-45.

Kriegstein A, Alvarez-Buylla A. 2009. The glial nature of embryonic and adult neural stem cells. Annu Rev Neurosci 32: $149-184$.

Kronenberg G, Reuter K, Steiner B, Brandt MD, Jessberger S, Yamaguchi M, Kempermann G. 2003. Subpopulations of proliferating cells of the adult hippocampus respond differently to physiologic neurogenic stimuli. J Comp Neurol 467: 455-463.

Kuhn HG, Dickinson-Anson H, Gage FH. 1996. Neurogenesis in the dentate gyrus of the adult rat: Age-related decrease of neuronal progenitor proliferation. J Neurosci 16: 2027-2033.

Kuhn HG, Winkler J, Kempermann G, Thal LJ, Gage FH. 1997. Epidermal growth factor and fibroblast growth factor-2 have different effects on neural progenitors in the adult rat brain. J Neurosci 17: 5820-5829.

Kuo CT, Mirzadeh Z, Soriano-Navarro M, Rasin M, Wang D, Shen J, Sestan N, Garcia-Verdugo J, Alvarez-Buylla A, Jan LY, et al. 2006. Postnatal deletion of Numb/Numblike reveals repair and remodeling capacity in the subventricular neurogenic niche. Cell 127: 1253-1264.

Lagace DC, Whitman MC, Noonan MA, Ables JL, DeCarolis NA, Arguello AA, Donovan MH, Fischer SJ, Farnbauch LA, Beech RD, et al. 2007. Dynamic contribution of nestin-expressing stem cells to adult neurogenesis. J Neurosci 27: $12623-12629$.

Leung CT, Coulombe PA, Reed RR. 2007. Contribution of olfactory neural stem cells to tissue maintenance and regeneration. Nat Neurosci 10: 720-726.

Levison SW, Goldman JE. 1993. Both oligodendrocytes and astrocytes develop from progenitors in the subventricular zone of postnatal rat forebrain. Neuron 10: 201-212.

Li L, Clevers H. 2010. Coexistence of quiescent and active adult stem cells in mammals. Science 327: 542-545.

Li S, Sun G, Murai K, Ye P, Shi Y. 2012. Characterization of TLX expression in neural stem cells and progenitor cells in adult brains. PLoS ONE 7: e43324.

Li G, Fang L, Fernandez G, Pleasure SJ. 2013. The ventral hippocampus is the embryonic origin for adult neural stem cells in the dentate gyrus. Neuron 78: 658-672.

Lim DA, Alvarez-Buylla A. 1999. Interaction between astrocytes and adult subventricular zone precursors stimulates neurogenesis. Proc Natl Acad Sci 96: 7526-7531.

Liu J, Solway K, Messing RO, Sharp FR. 1998. Increased neurogenesis in the dentate gyrus after transient global ischemia in gerbils. J Neurosci 18: 7768-7778.

Liu X, Wang Q, Haydar TF, Bordey A. 2005. Nonsynaptic GABA signaling in postnatal subventricular zone controls proliferation of GFAP-expressing progenitors. Nat Neurosci 8: 1179-1187.

Liu C, Sage JC, Miller MR, Verhaak RG, Hippenmeyer S, Vogel H, Foreman O, Bronson RT, Nishiyama A, Luo L, et al. 2011. Mosaic analysis with double markers reveals tumor cell of origin in glioma. Cell 146: 209-221.

Lu CP, Polak L, Rocha AS, Pasolli HA, Chen SC, Sharma N, Blanpain C, Fuchs E. 2012. Identification of stem cell 
populations in sweat glands and ducts reveals roles in homeostasis and wound repair. Cell 150: 136-150.

Lugert S, Basak O, Knuckles P, Haussler U, Fabel K, Gotz M, Haas CA, Kempermann G, Taylor V, Giachino C. 2010 Quiescent and active hippocampal neural stem cells with distinct morphologies respond selectively to physiological and pathological stimuli and aging. Cell Stem Cell 6: 445-456.

Ma DK, Bonaguidi MA, Ming GL, Song H. 2009. Adult neural stem cells in the mammalian central nervous system. Cell Res 19: 672-682.

Magavi SS, Leavitt BR, Macklis JD. 2000. Induction of neurogenesis in the neocortex of adult mice. Nature 405: 951-955.

Mascre G, Dekoninck S, Drogat B, Youssef KK, Brohee S, Sotiropoulou PA, Simons BD, Blanpain C. 2012. Distinct contribution of stem and progenitor cells to epidermal maintenance. Nature 489: 257-262.

Menn B, Garcia-Verdugo JM, Yaschine C, Gonzalez-Perez O, Rowitch D, Alvarez-Buylla A. 2006. Origin of oligodendrocytes in the subventricular zone of the adult brain. $J$ Neurosci 26: 7907-7918

Merkle FT, Tramontin AD, Garcia-Verdugo JM, AlvarezBuylla A. 2004. Radial glia give rise to adult neural stem cells in the subventricular zone. Proc Natl Acad Sci 101: $17528-17532$.

Merkle FT, Mirzadeh Z, Alvarez-Buylla A. 2007. Mosaic organization of neural stem cells in the adult brain. Science 317: 381-384.

Mich JK, Signer RA, Nakada D, Pineda A, Burgess RJ, Vue TY, Johnson JE, Morrison SJ. 2014. Prospective identification of functionally distinct stem cells and neurosphere-initiating cells in adult mouse forebrain. eLife 3 : e02669.

Ming GL, Song H. 2011. Adult neurogenesis in the mammalian brain: Significant answers and significant questions. Neuron 70: 687-702.

Mirzadeh Z, Merkle FT, Soriano-Navarro M, Garcia-Verdugo JM, Alvarez-Buylla A. 2008. Neural stem cells confer unique pinwheel architecture to the ventricular surface in neurogenic regions of the adult brain. Cell Stem Cell 3: 265-278.

Molofsky AV, Slutsky SG, Joseph NM, He S, Pardal R, Krishnamurthy J, Sharpless NE, Morrison SJ. 2006. Increasing p16 ${ }^{I N K 4 a}$ expression decreases forebrain progenitors and neurogenesis during ageing. Nature 443: 448-452.

Morshead CM, Reynolds BA, Craig CG, McBurney MW, Staines WA, Morassutti D, Weiss S, van der Kooy D. 1994. Neural stem cells in the adult mammalian forebrain: A relatively quiescent subpopulation of subependymal cells. Neuron 13: 1071-1082.

Mustroph ML, Chen S, Desai SC, Cay EB, DeYoung EK, Rhodes JS. 2012. Aerobic exercise is the critical variable in an enriched environment that increases hippocampal neurogenesis and water maze learning in male C57BL/6 mice. Neuroscience 219: 62-71.

Nait-Oumesmar B, Decker L, Lachapelle F, Avellana-Adalid V, Bachelin C, Baron-Van Evercooren A. 1999. Progenitor cells of the adult mouse subventricular zone proliferate, migrate and differentiate into oligodendrocytes after demyelination. Eur J Neurosci 11: 4357-4366.
Neural Precursors in the Adult Mammalian Brain

Nam HS, Benezra R. 2009. High levels of Id1 expression define B1 type adult neural stem cells. Cell Stem Cell 5: 515-526.

Niu W, Zang T, Zou Y, Fang S, Smith DK, Bachoo R, Zhang CL. 2013. In vivo reprogramming of astrocytes to neuroblasts in the adult brain. Nat Cell Biol 15: 1164-1175.

Ortega F, Gascon S, Masserdotti G, Deshpande A, Simon C, Fischer J, Dimou L, Chichung Lie D, Schroeder T, Berninger B. 2013. Oligodendrogliogenic and neurogenic adult subependymal zone neural stem cells constitute distinct lineages and exhibit differential responsiveness to Wnt signalling. Nat Cell Biol 15: 602-613.

Paez-Gonzalez P, Abdi K, Luciano D, Liu Y, Soriano-Navarro M, Rawlins E, Bennett V, Garcia-Verdugo JM, Kuo CT. 2011. Ank3-dependent SVZ niche assembly is required for the continued production of new neurons. Neuron 71: 61-75.

Paik JH, Ding Z, Narurkar R, Ramkissoon S, Muller F, Kamoun WS, Chae SS, Zheng H, Ying H, Mahoney J, et al. 2009. FoxOs cooperatively regulate diverse pathways governing neural stem cell homeostasis. Cell Stem Cell 5: 540-553.

Palmer TD, Markakis EA, Willhoite AR, Safar F, Gage FH. 1999. Fibroblast growth factor-2 activates a latent neurogenic program in neural stem cells from diverse regions of the adult CNS. J Neurosci 19: 8487-8497.

Palmer TD, Willhoite AR, Gage FH. 2000. Vascular niche for adult hippocampal neurogenesis. J Comp Neurol 425: 479-494.

Parent JM, Yu TW, Leibowitz RT, Geschwind DH, Sloviter RS, Lowenstein DH. 1997. Dentate granule cell neurogenesis is increased by seizures and contributes to aberrant network reorganization in the adult rat hippocampus. J Neurosci 17: 3727-3738.

Parent JM, Vexler ZS, Gong C, Derugin N, Ferriero DM. 2002. Rat forebrain neurogenesis and striatal neuron replacement after focal stroke. Ann Neurol 52: 802-813.

Pastrana E, Cheng LC, Doetsch F. 2009. Simultaneous prospective purification of adult subventricular zone neural stem cells and their progeny. Proc Natl Acad Sci 106: 6387-6392.

Pfenninger CV, Roschupkina T, Hertwig F, Kottwitz D, Englund E, Bengzon J, Jacobsen SE, Nuber UA. 2007. CD133 is not present on neurogenic astrocytes in the adult subventricular zone, but on embryonic neural stem cells, ependymal cells, and glioblastoma cells. Cancer Res 67: 5727-5736.

Piatti VC, Davies-Sala MG, Esposito MS, Mongiat LA, Trinchero MF, Schinder AF. 2011. The timing for neuronal maturation in the adult hippocampus is modulated by local network activity. J Neurosci 31: 7715-7728.

Platel JC, Dave KA, Gordon V, Lacar B, Rubio ME, Bordey A. 2010. NMDA receptors activated by subventricular zone astrocytic glutamate are critical for neuroblast survival prior to entering a synaptic network. Neuron 65: 859872.

Ponti G, Obernier K, Guinto C, Jose L, Bonfanti L, AlvarezBuylla A. 2013. Cell cycle and lineage progression of neural progenitors in the ventricular-subventricular zones of adult mice. Proc Natl Acad Sci 110: E1045-E1054.

Qian X, Shen Q, Goderie SK, He W, Capela A, Davis AA, Temple S. 2000. Timing of CNS cell generation: A pro- 
M.A. Bonaguidi et al.

grammed sequence of neuron and glial cell production from isolated murine cortical stem cells. Neuron 28: 6980

Renault VM, Rafalski VA, Morgan AA, Salih DA, Brett JO, Webb AE, Villeda SA, Thekkat PU, Guillerey C, Denko NC, et al. 2009. FoxO3 regulates neural stem cell homeostasis. Cell Stem Cell 5: 527-539.

Riquelme PA, Drapeau E, Doetsch F. 2008. Brain microecologies: Neural stem cell niches in the adult mammalian brain. Philos Trans R Soc Lond B Biol Sci 363: 123 137.

Robel S, Berninger B, Gotz M. 2011. The stem cell potential of glia: Lessons from reactive gliosis. Nat Rev Neurosci 12: $88-104$.

Rossi C, Angelucci A, Costantin L, Braschi C, Mazzantini M, Babbini F, Fabbri ME, Tessarollo L, Maffei L, Berardi N, et al. 2006. Brain-derived neurotrophic factor (BDNF) is required for the enhancement of hippocampal neurogenesis following environmental enrichment. Eur J Neurosci 24: $1850-1856$.

Sawamoto K, Wichterle H, Gonzalez-Perez O, Cholfin JA, Yamada M, Spassky N, Murcia NS, Garcia-Verdugo JM, Marin O, Rubenstein JL, et al. 2006. New neurons follow the flow of cerebrospinal fluid in the adult brain. Science 311: 629-632.

Schofield R. 1978. The relationship between the spleen colony-forming cell and the haemopoietic stem cell. Blood Cells 4: 7-25.

Schuurmans C, Guillemot F. 2002. Molecular mechanisms underlying cell fate specification in the developing telencephalon. Curr Opin Neurobiol 12: 26-34.

Seri B, Garcia-Verdugo JM, McEwen BS, Alvarez-Buylla A. 2001. Astrocytes give rise to new neurons in the adult mammalian hippocampus. J Neurosci 21: 7153-7160.

Seri B, Garcia-Verdugo JM, Collado-Morente L, McEwen BS, Alvarez-Buylla A. 2004. Cell types, lineage, and architecture of the germinal zone in the adult dentate gyrus. J Comp Neurol 478: 359-378.

Shen Q, Wang Y, Kokovay E, Lin G, Chuang SM, Goderie SK, Roysam B, Temple S. 2008. Adult SVZ stem cells lie in a vascular niche: A quantitative analysis of niche cell-cell interactions. Cell Stem Cell 3: 289-300.

Sierra A, Encinas JM, Deudero JJ, Chancey JH, Enikolopov G, Overstreet-Wadiche LS, Tsirka SE, Maletic-Savatic M 2010. Microglia shape adult hippocampal neurogenesis through apoptosis-coupled phagocytosis. Cell Stem Cell 7: 483-495.

Simons BD, Clevers H. 2011. Strategies for homeostatic stem cell self-renewal in adult tissues. Cell 145: 851-862.

Sirko S, Behrendt G, Johansson PA, Tripathi P, Costa M, Bek S, Heinrich C, Tiedt S, Colak D, Dichgans M, et al. 2013. Reactive glia in the injured brain acquire stem cell properties in response to sonic hedgehog. Cell Stem Cell 12: $426-439$.

Snyder JS, Soumier A, Brewer M, Pickel J, Cameron HA. 2011. Adult hippocampal neurogenesis buffers stress responses and depressive behaviour. Nature 476: 458-461.

Snyder JS, Ferrante SC, Cameron HA. 2012. Late maturation of adult-born neurons in the temporal dentate gyrus. PLOS ONE 7: e48757.
Song H, Stevens CF, Gage FH. 2002. Astroglia induce neurogenesis from adult neural stem cells. Nature 417: 39-44.

Song J, Zhong C, Bonaguidi MA, Sun GJ, Hsu D, Gu Y, Meletis K, Huang ZJ, Ge S, Enikolopov G, et al. 2012. Neuronal circuitry mechanism regulating adult quiescent neural stem-cell fate decision. Nature 489: 150-154.

Spassky N, Merkle FT, Flames N, Tramontin AD, GarciaVerdugo JM, Alvarez-Buylla A. 2005. Adult ependymal cells are postmitotic and are derived from radial glial cells during embryogenesis. J Neurosci 25: 10-18.

Steiner B, Kronenberg G, Jessberger S, Brandt MD, Reuter K, Kempermann G. 2004. Differential regulation of gliogenesis in the context of adult hippocampal neurogenesis in mice. Glia 46: 41-52.

Steiner B, Klempin F, Wang L, Kott M, Kettenmann H, Kempermann G. 2006. Type-2 cells as link between glial and neuronal lineage in adult hippocampal neurogenesis. Glia 54: 805-814.

Steiner B, Zurborg S, Horster H, Fabel K, Kempermann G. 2008. Differential $24 \mathrm{~h}$ responsiveness of Prox1-expressing precursor cells in adult hippocampal neurogenesis to physical activity, environmental enrichment, and kainic acid-induced seizures. Neuroscience 154: 521-529.

Stranahan AM, Khalil D, Gould E. 2006. Social isolation delays the positive effects of running on adult neurogenesis. Nat Neurosci 9: 526-533.

Suh H, Consiglio A, Ray J, Sawai T, D'Amour KA, Gage FH. 2007. In vivo fate analysis reveals the multipotent and self-renewal capacities of Sox $2^{+}$neural stem cells in the adult hippocampus. Cell Stem Cell 1: 515-528.

Tashiro A, Makino H, Gage FH. 2007. Experience-specific functional modification of the dentate gyrus through adult neurogenesis: A critical period during an immature stage. J Neurosci 27: 3252-3259.

Tavazoie M, Van der Veken L, Silva-Vargas V, Louissaint M, Colonna L, Zaidi B, Garcia-Verdugo JM, Doetsch F. 2008. A specialized vascular niche for adult neural stem cells. Cell Stem Cell 3: 279-288.

Tsai HH, Li H, Fuentealba LC, Molofsky AV, Taveira-Marques R, Zhuang H, Tenney A, Murnen AT, Fancy SP, Merkle F, et al. 2012. Regional astrocyte allocation regulates CNS synaptogenesis and repair. Science 337: 358-362.

van Praag H, Kempermann G, Gage FH. 1999. Running increases cell proliferation and neurogenesis in the adult mouse dentate gyrus. Nat Neurosci 2: 266-270.

Villeda SA, Luo J, Mosher KI, Zou B, Britschgi M, Bieri G, Stan TM, Fainberg N, Ding Z, Eggel A, et al. 2011. The ageing systemic milieu negatively regulates neurogenesis and cognitive function. Nature 477: 90-94.

Waddington CH. 1957. The strategy of the genes; A discussion of some aspects of theoretical biology. Allen \& Unwin, London.

Wilson A, Laurenti E, Oser G, van der Wath RC, BlancoBose W, Jaworski M, Offner S, Dunant CF, Eshkind L, Bockamp E, et al. 2008. Hematopoietic stem cells reversibly switch from dormancy to self-renewal during homeostasis and repair. Cell 135: 1118-1129.

* Wu MV, Sahay A, Duman RS, Hen R. 2015. Functional differentiation of adult-born neurons along the septotemporal axis of the dentate gyrus. Cold Spring Harb Perspect Biol doi: 10.1101/cshperspect.a018978. 
Neural Precursors in the Adult Mammalian Brain

Young KM, Fogarty M, Kessaris N, Richardson WD. 2007. Subventricular zone stem cells are heterogeneous with respect to their embryonic origins and neurogenic fates in the adult olfactory bulb. J Neurosci 27: 8286-8296.

Zappaterra MW, Lehtinen MK. 2012. The cerebrospinal fluid: Regulator of neurogenesis, behavior, and beyond. Cell Mol Life Sci 69: 2863-2878.

Zhang Y, Barres BA. 2010. Astrocyte heterogeneity: An underappreciated topic in neurobiology. Curr Opin Neurobiol 20: 588-594.

Zhang RL, Zhang ZG, Wang Y, LeTourneau Y, Liu XS, Zhang X, Gregg SR, Wang L, Chopp M. 2007. Stroke induces ependymal cell transformation into radial glia in the subventricular zone of the adult rodent brain. J Cereb Blood Flow Metab 27: 1201-1212.

Zhao C, Deng W, Gage FH. 2008. Mechanisms and functional implications of adult neurogenesis. Cell 132: 645660.

Zhu X, Hill RA, Dietrich D, Komitova M, Suzuki R, Nishiyama A. 2011. Age-dependent fate and lineage restriction of single NG2 cells. Development 138: 745-753.

Zupanc GK, Sirbulescu RF. 2011. Adult neurogenesis and neuronal regeneration in the central nervous system of teleost fish. Eur J Neurosci 34: 917-929. 


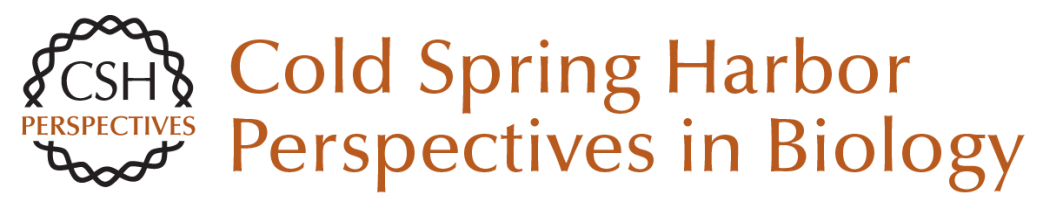

\section{Diversity of Neural Precursors in the Adult Mammalian Brain}

Michael A. Bonaguidi, Ryan P. Stadel, Daniel A. Berg, Jiaqi Sun, Guo-li Ming and Hongjun Song

Cold Spring Harb Perspect Biol 2016; doi: 10.1101/cshperspect.a018838 originally published online March 17, 2016

\section{Subject Collection Neurogenesis}

Adult Neurogenesis and Psychiatric Disorders Eunchai Kang, Zhexing Wen, Hongjun Song, et al.

Neuronal Circuitry Mechanisms Regulating Adult Mammalian Neurogenesis Juan Song, Reid H.J. Olsen, Jiaqi Sun, et al.

Neurogenesis in the Developing and Adult Brain

--Similarities and Key Differences

Magdalena Götz, Masato Nakafuku and David Petrik

Genetics and Epigenetics in Adult Neurogenesis Jenny Hsieh and Xinyu Zhao

The Adult Ventricular-Subventricular Zone (V-SVZ) and Olfactory Bulb (OB) Neurogenesis Daniel A. Lim and Arturo Alvarez-Buylla

Diversity of Neural Precursors in the Adult Mammalian Brain Michael A. Bonaguidi, Ryan P. Stadel, Daniel A. Berg, et al.

Detection and Phenotypic Characterization of Adult Neurogenesis $H$. Georg Kuhn, Amelia J. Eisch, Kirsty Spalding, et al.

Maturation and Functional Integration of New Granule Cells into the Adult Hippocampus Nicolas Toni and Alejandro F. Schinder
Adult Olfactory Bulb Neurogenesis

Pierre-Marie Lledo and Matt Valley

Adult Neurogenesis in Fish Julia Ganz and Michael Brand

In Vitro Models for Neurogenesis Hassan Azari and Brent A. Reynolds

Engineering of Adult Neurogenesis and Gliogenesis

Benedikt Berninger and Sebastian Jessberger

Computational Modeling of Adult Neurogenesis James B. Aimone

Control of Adult Neurogenesis by Short-Range Morphogenic-Signaling Molecules

Youngshik Choe, Samuel J. Pleasure and Helena Mira

Adult Neurogenesis: An Evolutionary Perspective Gerd Kempermann

Epilepsy and Adult Neurogenesis

Sebastian Jessberger and Jack M. Parent

For additional articles in this collection, see http://cshperspectives.cshlp.org/cgi/collection/

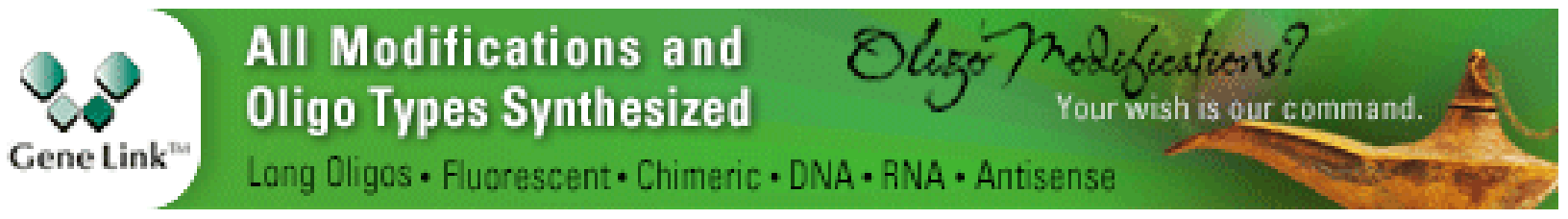


For additional articles in this collection, see http://cshperspectives.cshlp.org/cgi/collection/

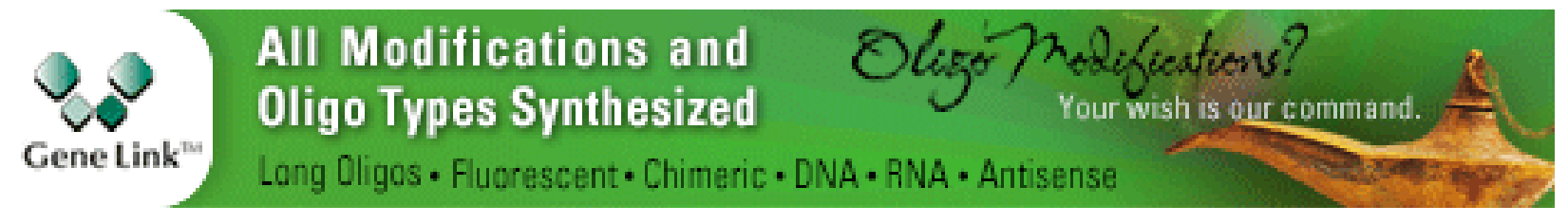

Copyright @ 2016 Cold Spring Harbor Laboratory Press; all rights reserved 